Annals of Warsaw University of Life Sciences - SGGW

Land Reclamation No 45 (1), 2013: 111-119

(Ann. Warsaw Univ. of Life Sci. - SGGW, Land Reclam. 45 (1), 2013)

\title{
Spatial and temporal variability of the interception in the natural wetland valley, the lower Biebrza basin case study
}

\author{
STEFAN IGNAR, ALEKSANDRA WĘGLEWSKA, SYLWIA SZPORAK- \\ -WASILEWSKA, JAROSŁAW CHORMAŃSKI \\ Department of Hydraulic Engineering, Warsaw University of Life Sciences - SGGW
}

\begin{abstract}
Spatial and temporal variability of the interception in the natural wetland valley, the lower Biebrza basin case study. The paper presents the research carried out in the lower basin of Biebrza River valley in order to identify interception for natural wetland plant communities. Maximum interception, i.e. the largest amount of water, expressed in millimeters, which can be captured and retained by plant canopy from rainfall is one of the key parameters of the water cycle modeling. Maximum interception was determined based on the difference of the masses of wet and dry fresh plant samples. Collection of plant material samples took place during the five measurement sessions, which began immediately after the flood recedes, and then lasted until the end of the growing season. Interception spatial variability was analyzed on the basis of the results of maximum interception measured for selected plant aggregations in the different sampling points. The obtained values were extrapolated to the area of the lower basin of Biebrza River using vegetation map of the Biebrza National Park. By conducting a test sessions in the five coming months, the maps of the spatial variability also show changes over time. Methodology used in the described tests allowed for obtaining of satisfactory results. They present, in a correct way, variation occurring between the plant aggregations due to their morphology. In most cases the results are consistent with data from the literature. As results of the analysis of spatial variability of the maximum interception, the highest values were found for the plant communities located in the immediate vicinity of the river channel. With the increase of the distance from river towards the valley edges the maximum interception values decrease. These changes can be seen in the form of strips parallel to the river channel, which corresponds to the
\end{abstract}

plant zones. Obtained map of spatial variability of the maximum interception, which is the results of extrapolation of the values assigned to plant communities, has a high correlation with the map resulting from the analysis of satellite images.

Key words: interception, riparian wetlands, plant communities

\section{INTRODUCTION}

Interception is a common process that occurs in nature involving the detention of precipitation on the surface of plants. It is one of the components of the surface water retention in river catchment. Interception allows for temporary increase of the catchment water resources with an increase of biologically active surface. It is of minor importance in the water balance for the urbanized catchment due to the generally low share of green areas and their monoculture nature. But for catchments with a dominant plant cover share of interception in the water balance increases. It is related to the occurrence of mixed and diverse plant communities capable of retaining a significant amount of precipitation. Volume of interception, which is the function of precipitation amount, varies with the land cover changes in time. It depends on factors like intensity, amount and distribution of 
precipitation, evaporation flux, and the shape, stand, size, and nature of leaves. The interception process can change the quantity, quality and distribution of precipitation reaching the soil surface. One of the key parameters of modeling of the water cycle is the maximum interception, i.e. the largest amount of water, expressed in millimeters, which can be captured and retained by plant canopy. Knowledge of the spatial variability of interception in the catchment area, dependent on the species composition and stage of development of individual plant communities can have a significant impact on improving quality of the water cycle research and modeling. It is particularly significant issue for wetland catchments with a very rich, variable plant cover. Water cycle of these catchment is very sensitive to climate change (Maksymiuk et al. 2008) and good quality hydrological models may enable prediction of such change and mitigation of its adverse effects. Knowledge of the size and dynamics of the phenomenon of interception will also allow for the effective implementation of information acquired by remote sensing methods into the hydrological models (Chormański and Batelaan 2011).

There is relatively little scientific works during which the interception measurements were conducted. The SWAT model uses, as the quantity of the interception, values between 0.10 and $0.50 \mathrm{~mm}$ (Sellers et al. 1986). In her work Soczyńska (1989) presents the collected data on the maximum interception for a number of species of vegetation. Monson et al. (1992) investigated the possibility of interception of 27 alpine species appearing near Glacier Lakes in Wyo- ming. He stated that the interception is greater than four times the maximum weight of the plant and it is $0.05 \mathrm{~mm}$ water column. Bradley et al. (2003) compared the 18 varieties of clover and set the maximum interception between 0.13 and $0.36 \mathrm{~mm}$. Kołodziej et al. (2005) presented results of long-term study of interception conducted for cereals. $\mathrm{He}$ shows that the amount of rainwater retained by cornfield per year can range from 5.2 to $81.6 \mathrm{~mm}$. Wohlfahrt et al. (2006) determined the average maximum interception for nine dominant mountain meadow species in the eastern Alps in the range of 0.04 to $0.41 \mathrm{~mm}$ or 0.01 to $0.31 \mathrm{~mm}$, depending on the measurement method. The first of these method was spraying plants with water (Calder et al. 1996; Dunkerley and Booth 1999; Bradley et al. 2003), the second dipping them in a tank of water (Wood et al. 1998). Spraying plants is considered to be a better method of simulating the natural process of wetting the plants by precipitation and more efficient method due to the formation of water droplets. However, research carried out in situ by Wohlfahrt et al. (2006), during which he measured the amount of water stored on vegetation in the form of dew, do not support this hypothesis.

The above summary of the results of measurements of the maximum interception shows how large is their variability. Therefore, to determine the maximum interception for selected group of vegetation, it is recommended to conduct separate measurements.

The purpose of the research carried out in the lower basin of Biebrza River valley was to identify interception for natural wetland plant communities. The 
final result of the work is determination of the variation of maximum interception during the growing season and the presentation of its spatial arrangement in the river valley.

\section{MATERIAL AND METHODS}

The lower basin of Biebrza River valley covers an area of glacial trough having a length of $30 \mathrm{~km}$ and a width of $12-15 \mathrm{~km}$. This area is bordered to the north by mid Biebrza basin, and the dividing line runs from Osowiec Twierdza to Sośnia and along the south edge of a Grajewski sandur to Klimaszewnica. To the south is the flood valley of the Narew River and the boundary runs between the valley of the lower Biebrza River and the Wizna and Tykocin valley (Banaszuk 2004). Flood terrace, occupying a large part of the lower basin, is formed by extensive peat bogs with an area of 21 thousand ha. The remaining area is mud river bed zone with a width of $1-2 \mathrm{~km}$ and with numerous ox-bows. The northern part of the lower basin of Biebrza River valley is located at an altitude of 107-108 m above sea level and gradually decreases towards the mouth of the river reaching 102-103 m above sea level in the Bagno Ławki area (Banaszuk 2004).

The study area is located within a climate zone "climates of the great valley lands", one of the seven market out on Polish territory, in the so-called Łomża-Grodno climate district. Average annual temperature is 6.5 to $7.0^{\circ} \mathrm{C}$, which is about $1-2^{\circ} \mathrm{C}$ lower than in the central and western Poland. The growing season lasts 187-206 days and is about 15-20 days shorter than in other regions of the country. The average annual rainfall is about 550 to $600 \mathrm{~mm}$, and in 2008 it was observed $600 \mathrm{~mm}$. Summer half-year precipitation exceeds winter half-year one by $26-30 \%$, which indicates a continental nature of the regional climate (Oświt 1973). In 2008 the water level remained above the ground from mid-January to early May, with a maximum of 25th March equal to $23 \mathrm{~cm}$. After the receding of flooding average depth of the water table was $25 \mathrm{~cm}$ below the ground surface.

Collection of plant material samples took place during the measurement sessions, which began immediately after the flood recedes, and then lasted until the end of the growing season. Table 1 presents the plant aggregations for which the measurements of the maximum interception were made.

Most of the selected plant aggregations belong to a class Phragmitetea, that is the class of bog rush plant communities. The first two aggregations listed in Table 1 belong to the class Scheuchzerio-Caricetea nigrae, the plant communities of fens, transition mires and valley structures on raised bogs. The study also examined the possibility of a maximum interception in the communities of anthropogenic origin. Contrasting plant aggregation as compared with plant vegetation of the swamp valley is $\mathrm{Co}$ rynephoretum canescentis, the aggregation of spiky blue grass representing the anthropogenic secondary vegetation.

Maximum interception was determined based on the difference of the masses of wet and dry samples. The plant sampling was made during the dry weather. Research plots were designated for each plant aggregation (two for Cari- 
TABLE 1. Characteristics of selected plant aggregations of the lower basin of Biebrza River valley chosen for field measurements

\begin{tabular}{|c|l|l|l|}
\hline No & Plant aggregation & Aggregation structure & Characteristic species \\
\hline 1 & $\begin{array}{l}\text { Carici canescentis- } \\
\text {-Agrostietum caninae }\end{array}$ & tufty & $\begin{array}{l}\text { Cares canescens } \\
\text { Agrostis canina }\end{array}$ \\
\hline 2 & Caricetum diandrae & tufty & Carex diandra \\
\hline 3 & Caricetum appropinquatae & tufty-valley & Carex appropinquata \\
\hline 4 & Caricetum ripariae & stolonate & Carex riparia \\
\hline 5 & Caricetum gracilis & stolonate & Carex gracilis \\
\hline 6 & Corynephoretum canescentis & tufty & Corynephorus canescens \\
\hline 7 & Phragmitetum australis & tufty-stolonate & Phragmites australis \\
\hline 8 & Calamagrostis canescens & tufty-stolonate & Calamagrostis canescens \\
\hline 9 & Arrhenatherion elatioris & loosely-tufty & Arrhenatherum elatius \\
\hline
\end{tabular}

cetum diandrae and Caricetum ripariae and three for Caricetum appropinquatae in different regions). Five samples of $100 \mathrm{~cm}^{2}$ designated with a wooden frame were collected from each research plot. The collected plant material was delivered to the laboratory, where each sample was weighed on a laboratory scale (WPS RADWAG 2100/C/2). The samples were then wetted by immersing them for about $10 \mathrm{sec}$ in a container filled with water. A short time was designed to reduce the penetration of water into the plants. Excess of water was allowed to drip; it took usually less than $10 \mathrm{sec}$. The plant material was next re-weighed. The whole procedure took less than $1 \mathrm{~min}$ in order to minimize water loss to evapotranspiration. The difference in the weight of dry and wet samples interception constituted the maximum interception.

Next, Pearson's correlation coefficients were determined between the obtained results of maximum interception measurements and the weight of dry fresh plant samples.

\section{RESULTS AND DISCUSSION}

The scope of work included the classification of plant aggregations in the field and plant sampling to determine the maximum interception based on the difference between the masses of wet and dry samples. Research was carried out in the growing season in 2008 in the five test sessions in May, June, July, August and September. Measurement spots have been indicated on the vegetation map of the lower basin within the Biebrza National Park. On this basis verification of identified plant aggregations was made.

Measurements results were placed in tables for successive months allowing for temporal variability analysis with amended phases of plant growth during the growing season. Table 2 is an example of results specification for August 2008. Also, for each test session the chart of maximum interception variability was developed as presented for $\mathrm{Au}$ gust in Figure 1. Conducted analysis of 
TABLE 2. Measurement results of the maximum interception and dry weight of fresh specimens for the studied plant aggregations in August 2008

\begin{tabular}{|r|l|l|ccc|c|}
\hline No. & $\begin{array}{l}\text { Place of } \\
\text { sampling }\end{array}$ & $\begin{array}{l}\text { Name of the tested plant aggre- } \\
\text { gations or dominant species }\end{array}$ & $\begin{array}{l}\text { Maximum interception } \\
\text { Average } \\
{[\mathrm{mm}]}\end{array}$ & $\begin{array}{c}\text { Maximum } \\
{[\mathrm{mm}]}\end{array}$ & $\begin{array}{c}\text { Minimum } \\
{[\mathrm{mm}]}\end{array}$ & $\begin{array}{c}\text { Average } \\
\text { sample } \\
\text { weight } \\
{[\mathrm{g}]}\end{array}$ \\
\hline 1 & Gugny & Carici-Agrostietum caninae & 2.50 & 2.71 & 1.96 & 44.35 \\
\hline 2 & Gugny & Caricetum appropinquatae I & 7.37 & 9.98 & 4.28 & 195.64 \\
\hline 3 & Gugny & Caricetum appropinquatae II & 4.42 & 5.27 & 2.68 & 91.75 \\
\hline 4 & Gugny & Caricetum appropinquatae III & 6.00 & 7.83 & 4.39 & 168.46 \\
\hline 5 & Gugny & Caricetum ripariae & 4.54 & 5.98 & 1.34 & 76.12 \\
\hline 6 & Gugny & Caricetum gracilis I & 1.70 & 2.80 & 1.12 & 42.63 \\
\hline 7 & Gugny & Caricetum gracilis II & 1.76 & 2.63 & 1.27 & 48.01 \\
\hline 8 & Gugny & Calamagrostis canescens & 4.15 & 6.71 & 2.07 & 108.06 \\
\hline 9 & Gugny & Corynephoretum canescentis & 1.51 & 2.40 & 0.85 & 21.49 \\
\hline 10 & Bagno Lawki & Caricetum diandrae I & 1.66 & 2.69 & 0.84 & 47.77 \\
\hline 11 & Bagno Lawki & Caricetum diandrae II & 2.83 & 4.06 & 1.49 & 78.53 \\
\hline 12 & Gugny & Phragmitetum australis & 5.21 & 6.02 & 2.05 & 71.98 \\
\hline 13 & Osowiec & Arrhenatherion & 0.87 & 1.48 & 0.43 & 12.67 \\
\hline
\end{tabular}

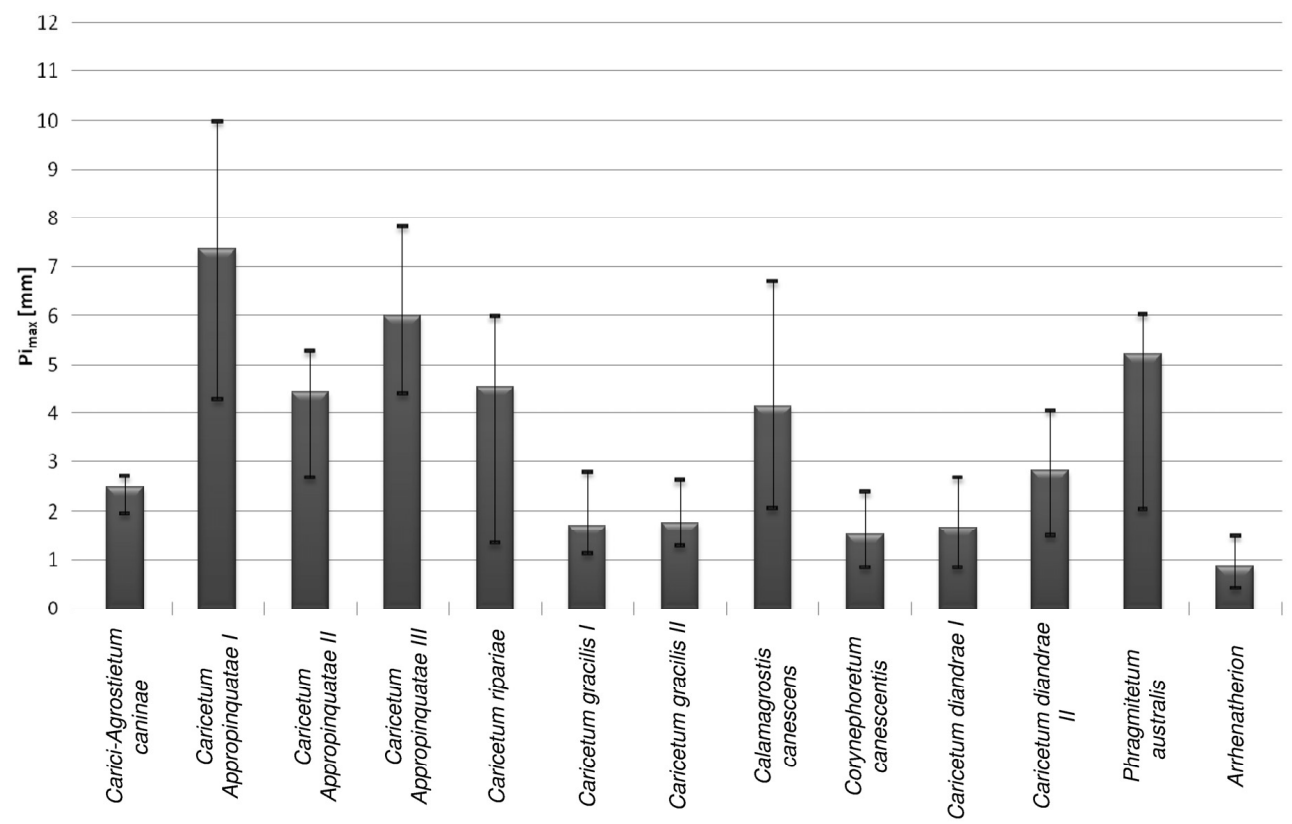

FIGURE 1. Maximum interception variability of selected plant communities in August 2008 (Węglewska 2009) 
temporal variability of measured maximum interception has shown that for examined plant aggregations it was possible to distinguish group with high values of maximum interception regardless of stage of development during the growing season. Following plant aggregations belongs to this group: Caricetum appropinquatae, Phragmitetum australis and Caricetum ripariae. Caricetum diandrae and Caricetum gracilis form group with mean values of maximum interception and Corynephoretum canescentis with Arrhenatherion elatioris belong to the group with lower values of interception.

Interception spatial variability was analyzed on the basis of the results of maximum interception measured for selected plant aggregations in the different sampling points. The obtained values were extrapolated to the area of the lower basin of Biebrza River using vegetation map of the Biebrza National Park. By conducting a test sessions in the five coming months, the maps of the spatial variability also show changes over time. Figure 2 presents the example of spatial variability of the maximum interception in the lower basin of Biebrza River in August 2008.

Map of spatial variability of the maximum interception, which is the results of extrapolation of the values assigned to plant communities in the area of the lower basin of the Biebrza River valley was compared with the map resulting from the analysis of satellite images.

The presence of a positive correlation was revealed between the obtained results of maximum interception measure- ments and the weight of dry fresh plant samples. It confirms results of works of Wood et al. (1998).

\section{CONCLUSIONS}

Methodology used in the tests, which consists of calculating the maximum interception from the difference between the masses of wet and dry samples of fresh plant material, allowed for obtaining of satisfactory results. They present, in a correct way, variation occurring between the plant aggregations due to their morphology. In most cases the results are consistent with data from the literature.

As results of the analysis of spatial variability of the maximum interception, the highest values were found for the plant communities located in the immediate vicinity of the river channel. With the increase of the distance from river towards the valley edges the maximum interception values decrease. These changes can be seen in the form of strips parallel to the river channel, which corresponds to the plant zones.

Map of spatial variability of the maximum interception, which is the results of extrapolation of the values assigned to plant communities in the area of the lower basin of the Biebrza River valley, has a high correlation with the map resulting from the analysis of satellite images.

Reported correlation between the maximum interception measurements and the weight of dry fresh plant samples allows for the calculation of interception knowing the plant sample weight. 
<smiles>NC(I)(I)I</smiles>

\section{Legend}

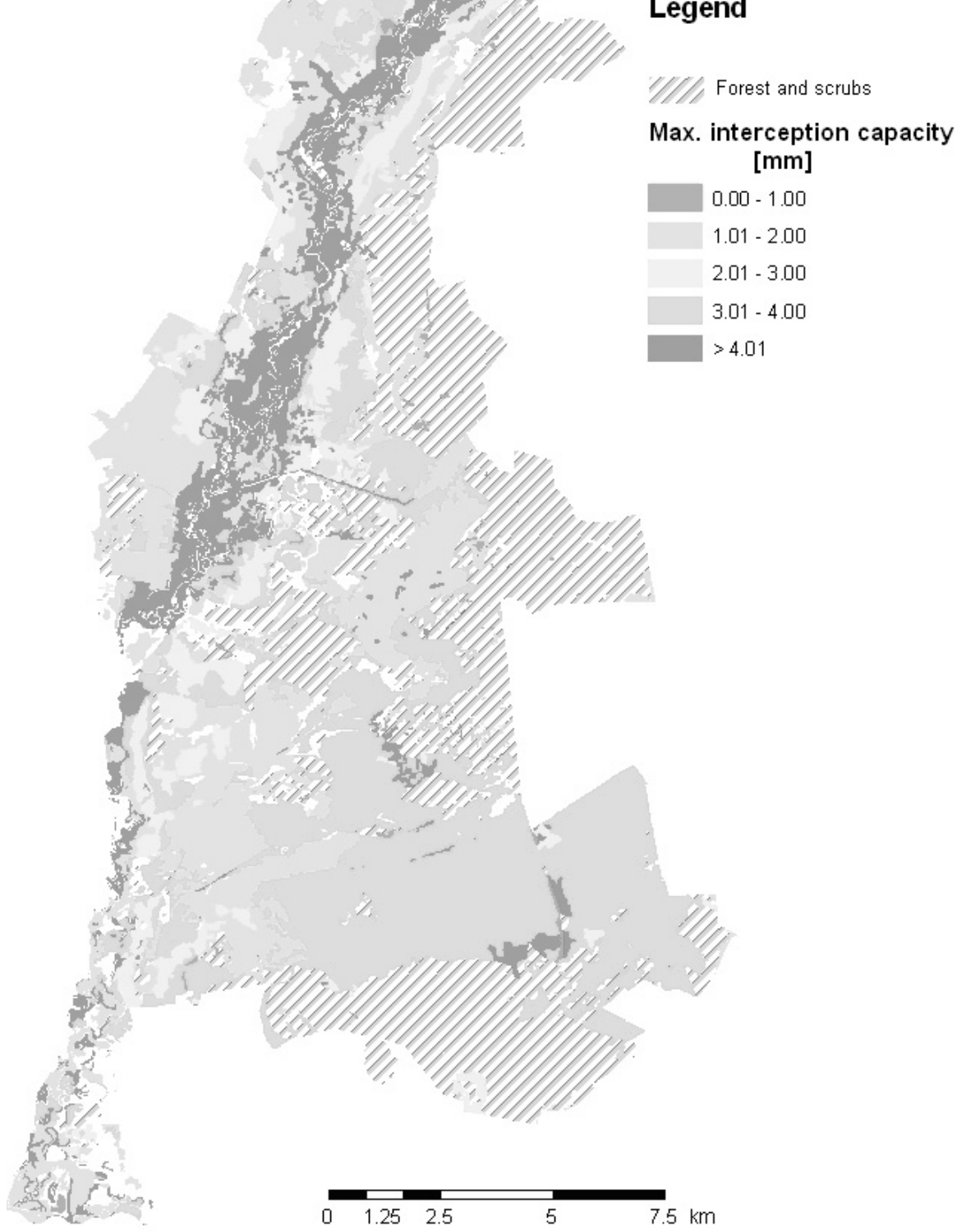

FIGURE 2. Spatial variability of the maximum interception in the lower basin of Biebrza in August 2008 


\section{REFERENCES}

BANASZUK H. 2004: Kotlina Biebrzańska i Biebrzański Park Narodowy. Aktualny stan, walory, zagrożenia i potrzeby czynnej ochrony środowiska [Biebrza Basin and Biebrza National Park. Current status, values, risks and the needs for active protection of the environment]. Economics and Environment Publishers, 527.

BRADLEY D.J., GILBERT G.S., PARKER I.M. 2003: Susceptibility of clover species to fungal infection: the interaction of leaf surface traits and the environment. American Journal of Botany 90, 857-864.

CALDER I.R., HALL R.L., ROSIER P.T.W., BASTABLE H.G., PRASANNA K.T. 1996: Dependence of rainfall interception on drop size:2. Experimental determination of the wetting functions and two layer stochastic model parameters for five tropical tree species. Journal of Hydrology 185, 379-388.

CHORMANSKI J., BATELAAN O. 2011: Application of the WetSpa distributed hydrological model for catchment with significant contribution of organic soil. Upper Biebrza case study. Annals of Warsaw University of Life Sciences - SGGW, Land Reclamation 43 (1), 25-35.

DUNKERLEY D., BOOTH T.L. 1999: Plant canopy interception of rainfall and its significance in a banded landscape, arid western New South Wales, Australia. $\mathrm{Wa}$ ter Resources Research 35, 1581-1586.

KOLODZIEJ J., LINIEWICZ K., BEDNAREK H. 2005: Intercepcja opadów atmosferycznych w łanach zbóż [Rainfall interception in cereal stands]. Acta Agrophysica 6 (2), 381-391 [Engl. summ].

MAKSYMIUK A., FURMANCZYK K., IGNAR S., KRUPA J., OKRUSZKO T. 2008: Analiza zmienności parametrów klimatycznych i hydrologicznych w dolinie rzeki Biebrzy [Analysis of climatic and hydrologic parameters variability in the Biebrza river basin]. Scientific Review
Engineering and Environmental Sciences 3 (41), 59-68 [Engl. summ.].

MONSON R.K., GRANT M.G., JAEGER C.H., SCHOETTLE A.W. 1992: Morphological causes for the retention of precipitation in the crowns of Alpine plants. Environmental and Experimental Botany 32, 319-327.

OŚWIT J. 1973: Warunki rozwoju torfowisk $\mathrm{w}$ dolinie dolnej Biebrzy na tle stosunków wodnych [Conditions of mire development in the Lower Biebrza valley versus water relations]. Polish Agricultural Annual D 143, 80.

SELLERS P.J., MINTZ Y., SUD Y.C., DALCHER A. 1986: A simple biosphere model $(\mathrm{SiB})$ for use within general circulation models. Journal of the Atmospheric Sciences 43, 505-531.

SOCZYŃSKA U. 1989: Procesy hydrologiczne: fizycznogeograficzne podstawy modelowania [Hydrological processes: physical and geographical base of modeling]. Polish Scientific Publishers, 245.

WĘGLEWSKA A. 2009: Time and extent variations of interception determination in natural boggy valley on example of lower Biebrza basin. Manuscript of MSc thesis, WULS.

WOHLFAHRT G., BIANCHI K., CERNUSCA A. 2006: Leaf and stem maximum water storage capacity of herbaceous plants in a mountain meadow. Journal of Hydrology, 319, 383-390.

WOODM.K.,JONEST.L.,VERA-CRUZM.T. 1998: Rainfall interception by selected plants in the Chihuahuan desert. Journal of Range Management 51, 91-96.

Streszczenie: Przestrzenna i czasowa zmienność intercepcji $w$ naturalnej dolinie bagiennej, analiza przypadku dolnego basenu rzeki Biebrzy. $\mathrm{W}$ artykule przedstawiono badania przeprowadzone w dolnym basenie doliny rzeki Biebrzy mające na celu rozpoznanie procesów intercepcji w naturalnych zbiorowiskach roślinnych obszarów mokradłowych. Intercepcja maksymalna, czyli ilość wody wyrażona w milimetrach jaką 
roślina może przechwycić i zatrzymać z opadu atmosferycznego, jest jednym z kluczowych parametrów modelowania cyklu wodnego. Intercepcja maksymalna została określona na podstawie różnicy mas próbek suchych i mokrych świeżych roślin. Pobór materiału roślinnego odbywał się podczas pięciu sesji pomiarowych, które rozpoczęto bezpośrednio po ustąpieniu zalewu i które trwały do końca okresu wegetacyjnego. Przestrzenna zmienność intercepcji była analizowana na podstawie wyników pomiarów intercepcji maksymalnej dla wybranych zespołów roślinnych w różnych punktach pomiarowych. Otrzymane wartości ekstrapolowano na obszar dolnego basenu Biebrzy z wykorzystaniem mapy roślinności Biebrzańskiego Parku Narodowego. Dzięki przeprowadzeniu sesji pomiarowych w kolejnych miesiącach, mapy zmienności przestrzennej przedstawiają również zmiany zachodzące $\mathrm{w}$ czasie. Zastosowana w opisanych badaniach metodyka pozwoliła na uzyskanie zadawalających wyników. Prezentują one w sposób prawidłowy zmienność występującą między zespołami roślinnymi, związaną z ich morfologią. W większości przypadków wyniki są zgodne $\mathrm{z}$ danymi $\mathrm{z}$ literatury. $\mathrm{W}$ wyniku analizy przestrzennej zmienności intercepcji maksymal- nej najwyższe wartości stwierdzono dla zbiorowisk położonych $\mathrm{w}$ bezpośrednim sąsiedztwie koryta rzecznego. Wraz ze wzrostem odległości od rzeki ku brzegom doliny wartości intercepcji maksymalnej maleją. Zmiany widoczne są w postaci pasów równoległych do koryta rzecznego, które odpowiadają strefom roślinnym. Mapa zmienności przestrzennej intercepcji maksymalnej, która powstała w wyniku ekstrapolacji wartości przypisanych zespołom roślinnym, wykazuje dużą korelację z mapą powstałą w wyniku analizy zdjęcia satelitarnego.

Stowa kluczowe: intercepcja, mokradła przybrzeżne, zbiorowiska roślinne

MS. received 28 June 2013

\section{Authors' address:}

Katedra Inżynierii Wodnej

Wydział Budownictwa i Inżynierii Środowiska SGGW

ul. Nowoursynowska 159

02-776 Warszawa, Poland

e-mail: stefan_ignar@sggw.pl 